\title{
Effect of Roller Burnishing Parameters on Roughness Surface and Hardness of Unalloyed S 355 J0 Steel by Using Response Surface Methodology
}

Tourab Mohamed ${ }^{1}$, Hamadache Hamid ${ }^{1}$, Aguib Salah², Belhadi Salim ${ }^{3}$

${ }^{1}$ Laboratory of Advenced Technology in Research Production Mechanical, Badji Mokhtar University, P.O. Box 12, Annaba 23000, Algeria. E-mail:mohtou@yahoo.fr, hamham36@yahoo.fr

${ }^{2}$ Dynamic of Engines and Vibroacoustic Laboratory, F.S.I., M.B. Boumerdes University, 35000 Algeria. E-mail :salah.ldmv@gmail.com

${ }^{3}$ Mechanics and Structures Laboratory (LMS), 8 Mai 1945 University, P.O. Box 401, Guelma 24000, Algeria. E-mail:belhadi.salim@yahoo.fr

Burnishing is a cold working process with superficial plastic deformation, which is to exert an external pressure through a very hard and smooth roller or ball on a surface to occur a uniform and work-hardened surface, to make it possible to reduce roughness, to increase the hardness and to produce residual stresses of compression. The unalloyed S $355 \mathrm{~J} 0$ steel specimens were machined on a conventional lathe to the proper dimensions; these machined specimens were then burnished by a simple locally designed and fabricated roller-burnishing tool. The main objective in this work is to determine a mathematical models statistically based on experimental design (response surface methodology) using central composite second-order rotatable design which allows to give the relationship between the two out parameters surface roughness and hardness, representative of the superficial layer surface caused by the four internal roller-burnishing parameters called: burnishing speed, force, feed and number of passes of the tool. The experimental results indicate that feed, burnishing force and speed are the most important and significant parameters to improve roughness surface, and feed, speed, burnishing force and number of passes are the most important and significant parameters to improve superficial hardness of S $355 \mathrm{J0}$ steel specimens. The surface roughness and hardness were improved from about $2.5 \mu \mathrm{m}$ to $0.15 \mu \mathrm{m}$ and from $176 \mathrm{HV}$ to $226 \mathrm{HV}$ respectively. The validated models with coefficient of determination $R^{2}=93.1 \%$ for surface roughness and $R^{2}=$ $\mathbf{8 9 . 8 \%}$ for hardness, seem correlate well with the experimental results.

Keywords: roller-burnishing, unalloyed S355J0 steel, surface roughness, superficial hardness, response surface methodology

\section{Acknowledgments}

This work was carried out at the mechanical manufacturing workshop of the National Engineering Institute of Mechanics (INGM), Boumerdes, Algeria. I thank Mr. Salah AGUIB for having me in their workshop and to have allowed me to work under excellent conditions.

Thanks to Mechanics and Structures Laboratory (LMS), University of Gulema-Algeria, for providing various supports for this study. We are also grateful to Dr. Salim BELHADI of LMS, for their help.

\section{References}

[1] MENDAR, A.C.E. (1978). Technical of burnishing, technique de galetage, Métaux et déformation, 1978, Vol. 47, pp. $45-56$.

[2] VASILKO, K., MURČINKOVÁ, Z. (2017). The proposal how to make the basic machining technologies - Turning, milling, planing - more productive, Manufacturing Technology, 2017, Vol. Nr. 2, pp. 261-267.

[3] OSIČKA, K., FIŠEROV Á, Z., OTOUPALÍK, J. (2017). Influence of cutting tool overhangs at machining of hardened steels, Manufacturing Technology, 2017, Vol. Nr. 2, pp. 261-267.

[4] HAMADACHE, H. LAOUAR, L. ZEGHI, N. E AND CHAOUI, K. (2006). Characteristics of Rb40 steel superficial layer under ball and roller burnishing, J. Materials Processing Technology, 2006, Vol. 180, Nr. 1-3, pp. 130-136.

[5] HASSAN, A. M., AL-BSHARAT, A. S. (1996). Influence of burnishing process on surface roughness, hardness, and microstructure of some non-ferrous metals, J. Wear, 1996, Vol. 199, Nr. 1, pp. 1-8.

[6] HASSAN, A. M. (1997). The effects of ball-and roller-burnishing on the surface roughness and hardness of some non-ferrous metals, J. Materials Processing Technology, 1997, Vol. 72, Nr. 3, pp. 385-391.

[7] HASSAN, A. M. (1997). An investigation into the surface characteristics of burnished cast Al Cu alloys, J. International of Machine Tools and Manufacture, 1997, Vol. 37, Nr. 6, pp. 813-821.

[8] RAJESHAM, S., TAK, J. C. (1989). A study on the surface characteristics of burnished components, J. Mechanical Working Technology, 1989, Vol. 20, pp. 129-138. 
[9] SEGAWA, T., SASAHARA, H., TSUTSUMI, M. (2004). Development of a new tool to generate compressive residual stress within a machined surface, J. International of Machine Tools and Manufacture, 2004, Vol. 44, Nr. 11, pp. 1215-1221,

[10] EL-TAWEEL, T. A., EBEID, S. J. (2009). Effect of hybrid electrochemical smoothing-roller burnishing process parameters on roundness error and micro-hardness, J. International of Advanced Manufacturing Technology, 2009, Vol. 42, Nr. 7-8, 643-655.

[11] PA, P. S. (2010). Continuous finishing processes using a combination of burnishing and electrochemical finishing on bore surfaces, J. International of Advanced Manufacturing Technology, 2010, Vol.49, Nr. 1-4, 147-154.

[12] EL-TAWEEL, T. A., EBEID, S. J. (2007). Improvement of roundness of cylindrical parts using hybrid electrochemical smoothing and roller burnishing process", Proceedings of the 35th International MATADOR Conference, Springer, 2007, London, pp. 85-88.

[13] TIAN, Y., SHIN, Y. C. (2007). Laser-assisted burnishing of metals, J. International of Machine Tools and Manufacture, 2007, Vol. 47, Nr. 1, pp. 14-22.

[14] HASSAN, A. M., MOMANI, A. M. (2000). Further improvements in some properties of shot peened components using the burnishing process, J. International of Machine Tools and Manufacture, 2000, Vol. 40, Nr. 12, pp. 1775-1786.

[15] El-AXIR, M. H., OTHMAN, O. M., ABODIENA, A. M. (2008). Study on the inner surface finishing of aluminum alloy 2014 by ball burnishing process, J. Materials Processing Technology, 2008, Vol. 202, Nr. 1, pp. 435-442.

[16] RAJESHAM, S., TAK, J. C. (1989). A study on the surface characteristics of burnished components, J. Mechanical Working Technology, 1989, Vol. 20, pp. 129-138.

[17] LEMERCIER, M. (1998). Emploi rationnel du galetage fin des surfaces, Techniques Industrielles, 1998, Vol. 92 , pp.69-79.

[18] EL-TAYEB, N. S. M., LOW, K. O., BREVERN, P. V. (2007). Influence of roller burnishing contact width and burnishing orientation on surface quality and tribological behaviour of Aluminium 6061, J. Materials Processing Technology, 2007, Vol. 186, Nr. 1, pp. 272-278.

[19] CHOMienne, V., VALIORGUE, F., RECH, J., VERDU, C. (2016). Influence of ball burnishing on residual stress profile of a 15-5PH stainless steel, J. Manufacturing Science and Technology, 2016, Vol. 13, pp. 90-96.

[20] WAGNER, L., LUDIAN, T., WOLLMANN, M. (2009). Ball-burnishing and roller-burnishing to improve fatigue performance of structural alloys, Engineering against Fracture, Springer, Netherlands, 2009, pp.1-11.

[21] ZHANG. P. LINDEMANN, J. (2005). Effect of roller burnishing on the high cycle fatigue performance of the high-strength wrought magnesium alloy AZ80, Scripta Materialia, 2005, Vol. 52, Nr. 10, pp. 1011-1015.

[22] WAGNER, K., PUTZ, A., ENGEL, U. (2006). Improvement of tool life in cold forging by locally optimized surfaces, J. Materials Processing Technology, 2006, Vol. 177, Nr. 1, pp. 206-209.

[23] SHIOU, F. J., CHEN, C. H. (2003). Freeform surface finish of plastic injection mold by using ball-burnishing process, J. Materials Processing Technology, 2003, Vol. 140, Nr 1, pp. 248-254.

[24] SHIOU, F. J., CHEN, C. C. A., LI, W. T. (2006). Automated surface finishing of plastic injection mold steel with spherical grinding and ball burnishing processes, J. International of Advanced Manufacturing Technology, 2006, Vol. 28, Nr. 1-2, 61-66.

[25] CHEVALIER, A., BOHAN, J. (1979). Manufacturing mechanical of technician, Guide du technicien en fabrication mécanique, Ed. Hachette technique, 1979.

[26] CORNET, A., DEVILLE, J.P. (1998). Physical and surface engineering, Physique et ingénierie des surfaces. Ed. EDP Sciences, 1998

[27] GOUPY, J., CREIGHTON, L. (2006). Introduction to experimental design, Introduction aux plans d'expériences, Ed. Dunod, 2006.

[28] BOX, G. E. HUNTER, J. S. (1957). Multi-factor experimental designs for exploring response surfaces, The Annals of Mathematical Statistics, 1957, Vol. 28, pp. 195-241.

[29] ČIERNA, H., ŤAVODOVA, M. (2013). Using the design of experiment method to evaluate quality of cuts after cutting aluminum alloy by AWJ. Manufacturing technology, 2013, Vol. Nr. 3, pp. 303-307. 